\title{
PRESCRIPTION VARIABLES FOR THE MEDICAL FOOTWEAR
}

\section{Daniel PETCU*}

INCDTP - Division: Leather and Footwear Research Institute, 93 Ion Minulescu St., Bucharest, Romania, email: crispinian.ro@gmail.com

Received: 08.09.2017 Accepted: 29.11.2017

https://doi.org/10.24264/Ifj.17.4.5

\section{PRESCRIPTION VARIABLES FOR THE MEDICAL FOOTWEAR}

ABSTRACT. Medical footwear is a medical device used in the conservative treatment of foot and lower limb pathomechanics. The standard EN ISO 9999:2016 - "Assistive products for person with disability-Classification and terminology", includes orthopedic shoes in the category of foot orthoses which are medical devices that encompass the whole or part of the foot, being divided in two categories: prefabricated or custom fabricated. According to the legal requirements, a custom fabricated device is based on a medical prescription containing the specific design characteristics as established by the medical practitioner. In many situations from clinical practice, the medical prescription does not contain the specific design characteristics but only some generic data such as the name and type of the orthopedic footwear. The purpose of this paper is to review the basic prescription variables of the medical footwear according to the experience from developed foot care systems. KEY WORDS: medical footwear, prescription variable

\section{VARIABILE DE PRESCRIPȚIE PENTRU ÎNCĂLȚĂMINTEA MEDICALĂ}

REZUMAT. Încălțămintea medicală este un dispozitiv medical utilizat în tratamentul conservator al patologiilor de natură mecanică ale piciorului și ale membrelor inferioare. Standardul EN ISO 9999: 2016 - „Produse de asistență pentru persoane cu dizabilități - clasificare și terminologie" include încălț̆mintea ortopedică în categoria ortezelor pentru picior care sunt dispozitive medicale ce cuprind întregul picior sau o parte a acestuia, fiind împărtite în două categorii: prefabricate sau personalizate. Conform cerintelor legale, un dispozitiv special fabricat se bazează pe o rețetă medicală care conține caracteristicile specifice de proiectare stabilite de către medic. În multe situații din practica clinică, prescripția medicală nu conține caracteristicile specifice de proiectare, ci doar câteva date generice precum denumirea și tipul încălțămintei ortopedice. Scopul acestei lucrări este de a revizui variabilele de bază ale prescripției pentru încălțămintea medicală, în conformitate cu experiența din sistemele dezvoltate de îngrijire a piciorului.

CUVINTE CHEIE: încălțăminte medicală, variabile de prescripție

\section{VARIABLES DE PRESCRIPTION POUR LES CHAUSSURES MÉDICALES}

RÉSUMÉ. Les chaussures médicales sont un dispositif médical utilisé dans le traitement conservateur de la pathomécanique du pied et du membre inférieur. La norme EN ISO 9999: 2016 - "Produits d'assistance pour personnes avec handicap - Classification et terminologie", inclut les chaussures orthopédiques dans la catégorie des orthèses pour les pieds qui sont des dispositifs médicaux qui englobent tout ou partie du pied, étant divisées en deux catégories: préfabriqués ou fabriqués sur mesure. Selon les exigences légales, un dispositif fabriqué sur mesure est basé sur une prescription médicale contenant les caractéristiques de conception spécifiques établies par le médecin. Dans de nombreuses situations de la pratique clinique, la prescription médicale ne contient pas les caractéristiques de conception spécifiques, mais seulement quelques données génériques comme le nom et le type de chaussure orthopédique. Le but de cet article est d'examiner les variables de prescription de base pour les chaussures médicales en fonction de l'expérience des systèmes développés de soin du pied.

MOTS CLÉS: chaussures médicales, variable de prescription

\footnotetext{
* Correspondence to: Daniel PETCU, INCDTP - Division: Leather and Footwear Research Institute, 93 lon Minulescu St., Bucharest, Romania, email: crispinian.ro@gmail.com
} 


\section{INTRODUCTION}

The orthopedic footwear is a foot orthosis, part of the lower limb orthoses category, defined as being "designed to modify the structural and functional characteristics of the neuromusculoskeletal systems of the lower limb" [1]. The literature dealing with medical footwear uses different terms to name it: "orthopaedic" [1], "therapeutic"-"diabetic"-“neuropathic" [2], "custom-moulded shoes" [3], "medical grade footwear" [4]. Despite all these confusing names, the importance of using the footwear as a medical device in the prevention of injuries, improving the performance or treatment of the foot and lower limb pathomechanics, is highlighted and documented on different levels of medical evidence by the large number of scientific literature dealing with the kinematic and kinetic effects of the footwear in different pathological or non-pathological conditions [5-7]. There are a lot of design characteristics considered starting from simple wedges in the studies related to medial knee osteoarthritis treatment [8], to complex designs as in those involved in the manipulation of the center of pressure used for training purposes [9]. In the case of custom fabricated medical devices the legal requirements ask for a medical prescription which is the responsibility of "a duly qualified medical practitioner" or "other person authorized by virtue of his professional qualification to do so" [10]. The problem of the lack of prescription variables of medical devices included in the medical prescription has been treated in the medical literature from an advanced system such as that of the USA pertaining to orthotics [11] or footwear [12]. It is notable that in the field of footwear, quite recently in 2013, Dennis Janisse - a renowned USA Cped, has given a "measure" of the lack of prescription variables, stating that "for every prescription we receive that reads, "Extra-depth shoes with Velcro closures, heel-to-toe rocker soles, extended steel shanks, custom Plastazote foot orthotics with MTH offloading, and partial foot filler on L," we get ten that read, "Shoes and inserts"'" [12]. A similar point of view regarding the increasing expertise of the orthotist while a physician's training decline is noticed in the field of orthotics prosthetics from USA was recently expressed [13]. The huge difference between the developments of the prescription form of the footwear between different countries could be seen by reviewing the models of prescription forms provided by the state insurance systems. For example, in Australian New South Wales state, the "Equipment Request Form" is 3 pages long asking very clear information related to footwear characteristics and regarding recommendation, justification or evaluation planning of the medical device [14]. In opposition with this situation, in Romania there is no specific template for the medical prescription of a custom fabricated medical device but a general one which only asks for the name and the type of the recommended medical device as information which can be categorized as specific design characteristics [15]. At the same time, there is no orthopedic footwear producer who would provide an online prescription form, this in opposition with the practice from USA where numerous companies are providing online prescription form for medical footwear. Moreover, in Romania the only book describing in detail the footwear characteristics in each chapter related to a foot pathology dates from 1964 [16]. The prescription definition and its implication especially in the countries where specific professions such as podiatry or pedorthics are not developed was extensively treated in a previous article [17]. As in the podiatric literature the foot orthotics are seen as "in-shoe" medical devices, numerous papers dealing with their prescription variables [18-20], the purpose of this paper was to 
focus on the specific prescription variables of the medical footwear, part of the medical prescription, without considering those of the "in-shoe" medical devices. These prescription variables could be part of the "technical prescription" elaborated by the physician or by orthotist/pedorthist according to their expertise highlighted by literature $[11,13,17]$.

\section{BASIC PRESCRIPTION VARIABLES}

The medical footwear is a complex product which is characterized by a multitude of design/manufacture characteristics. It is obvious that not any design characteristic should be a prescription variable to be included in the medical prescription. This is the reason for which, according to the purpose of this paper, the design/manufacture variables should be divided into two categories:

- prescription variables: those design characteristics which are essential for the medical footwear in order to achieve the medical objectives and in agreement with the functional description established by the medical practitioner;

- technical variables: those design characteristics that are not essential for the medical footwear in order to achieve the conservative treatment objectives established by the physician. These are established by the technical specialist (pedorthist, orthopedic shoemaster, orthotist). We consider that, even if they are essential, the technical variables related to the achievement of a good fitting of the medical footwear should be in the area of the technical specialist competences.

According to the legal rules, the prefabricated devices which are modified for therapeutic purposes are not considered custommade devices. Even in this condition as they are a therapeutic option for the conservative treatment of foot pathomechanics, they contain specific design characteristics which makes them suitable for this purpose. This is the reason for which the analysis of the prescription variables of the medical footwear is valid also for the prefabricated (or mass-produced) devices. It is not the intent of the present paper to describe in detail the characteristics of the prescription variables. The main objective of this paper is to present a list of basic prescription variables which can increase the awareness regarding the potential use of the footwear in the conservative treatment of foot pathomechanics.

The basic prescription variables for each important section are presented below.

\section{Footwear's Last and Foot's Cast Prescription Variables}

- Foot casting / scanning position. Generally, the semi-weight bearing casting position could be considered the reference position for casting but in special cases, casting in the position of function (for example in standing position as for the severe rigid deformities) or under partial pressure with slight manipulation or correction is recommended [21-25].

- Cast modifications. These are very well documented in the case of functional foot orthotics or lower limb orthoses and prostheses $[20,26]$. The most encountered modifications in the case of orthopedic footwear are related to cast balancing, creating a toe rise, adding a toe box and adding material in order to accommodate the sensitive areas [21-25].

- Type: curved / semicurved / straight should be indicated in agreement with foot shape [24]. This prescription variable should be indicated as in many cases the final last is obtained through modification of an existing straight last which will not give adequate results for C-shaped feet.

- Sagittal profile. The sagittal profile of the bottom part of the last has the potential to influence the subject's posture through a more correct weight distribution between rearfoot and forefoot [27]. It is important also for in-shoe 
medical devices stability inside the footwear.

- Last's heel height or elevation is an important prescription variable related to footwear balance in the sagittal plane [24, 25].

- Depth / extra depth. It will create the necessary allowances for accommodating inshoe medical devices or feet deformities. In the case of lower limb discrepancy, when a tapered raise is prescribed, the measurement under heel and metatarsophalangeal area should be provided [28]. An adequate space inside the footwear should be provided if foot or ankle foot orthoses which encompass the lateral or dorsal areas of the foot are prescribed [29].

- Girth last allowance is defined as a decreasing of the last's girth relative to the foot's girth in different sections of the midfoot or forefoot [30]. Together with the shoe's upper material's stiffness it will influence the pressure and friction at the foot-upper interface. Generally, mass produced footwear lasts are made with a smaller ball girth than foot ball girth.

- Bottom curvature in the metatarsophalangeal area (marked with " $A$ " in Figure 1). This curvature is a characteristic of the mass produced lasts. Together with the girth's last allowance it has two main roles: a functional one (to allow the stability of the foot inside the footwear through the reduction of the frictional forces between foot and shoe uppers) and a design role (to create the appearance of a "slim" foot in its largest width area). The curvature of the bottom part of the last has the potential to place the first metatarso-phalangeal joint in a dorsiflexed position related to the second to forth metatarsal joint. The negative effects of this positioning of the metatarsal joints could be the increasing of pressure under the central metatarsal joint [31] and the facilitation in time of the development of the functional hallux limitus.

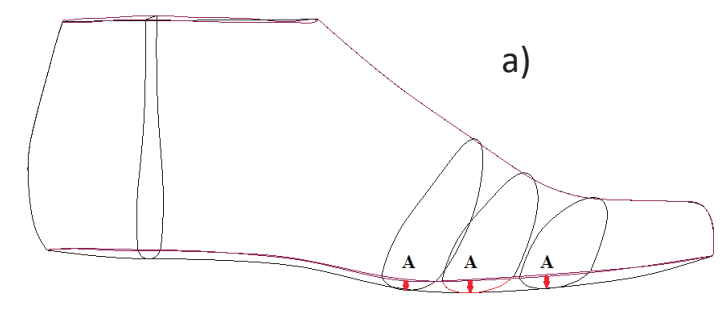

Figure 1. The curvature of the bottom part of the shoe last (marked with "A") a) frontal sections in the lateral view,

b) section in the ball area, perspective view

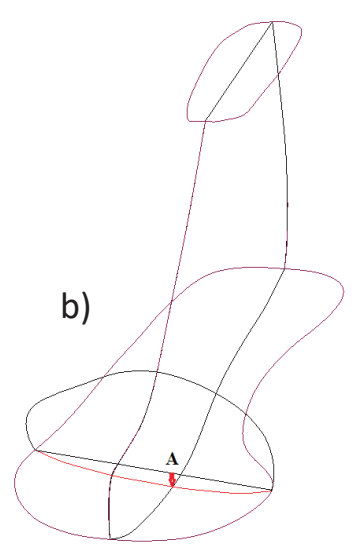

- 3-point force system. The application of a 3 point force system is mentioned as a potential method to modify the forefootrearfoot transversal plane relation [32] but specific data about how a last should be designed are not available. A good reference point could be the experience gained based on the use of the two-piece adjustable orthosis initially set for $20-25^{\circ}$ outflare in the case of flexible or rigid metatarsus adductovarus and allowing the manipulation of the position of the forefoot relative to the rearfoot in the transversal plane $[33,34]$. Important to be mentioned is that the outflare angle (from $20-25^{\circ}$ initially to $45^{\circ}$ after 4-6 weeks) and time of wearing (from 21-24 hours/day to $16-18$ hours/day) are subjects of prescription [34].

\section{Shoe Sole's Prescription Variables}

- Wedges are built in the structure of the sole as varus or valgus wedges and placed in the rearfoot or forefoot area. The main purpose is 
to modify the position of the center of pressure which is the point of application of ground reaction force $[24,35]$.

- Flares are built on the medial, lateral or posterior walls of the sole allowing more center of pressure displacement with a potential to influence the pronator or supinator moments through modifying the moment arm of the ground reaction vector around various lower extremity joints axis.

- Wide base is practically a medial, lateral and posterior flare built on the same sole.

- Lifts are used in the case of lower limb discrepancies when this cannot be accommodated only with in-shoe heel lift. The length of the heel lift should be indicated. In the case of a full length lift when a tapered raise is prescribed, the measurement underheeland metatarsophalangeal area should be provided [28].

- Variable stiffness shoes soles are built with different stiffness values of the medial and lateral part, with the stiffer lateral one creating a valgus wedge effect in dynamics [36, 37].

- Rocker soles are utilized to facilitate the forward movement around the heel, ankle or metatarso-phalangeal joints as pivoting centers or to decrease the plantar pressure under the metatarso-phalangeal joint [6]. As a function of the placement of the rocker point relative to the joint of interest, there are different types: negative heel, double or forefoot rocker. Modifying the angle rocker influences the value of the pressure under metatarso-phalangeal joints [38]. Standard types could be defined according to the joint of interest (ankle joint rocker, Lisfranc rocker, heel rocker, etc.). Materials with different density or stiffness used in different areas of the sole as in the case of MBT shoes have for example the purpose to create instability as the main action of a training device [39]. Changing the rocker sole profile's orientation relative to the line of progression has the potential to influence the ankle joint's range of motion [40].
- S.A.C.H heel (Solid Ankle Cushion Heel) - is prescribed for shock absorption purposes being built as an wedge in the proximal area of the sole, from a material with lower stiffness compared with the rest of the sole's material [41]. The same principle behind the S.A.C.H could be applied to prescribe dynamic inverted or everted heels [24, 25].

- Heel modifications are known as Thomas heel, having the medial part extended distal or reverse Thomas having the lateral part extended distal. The main purpose is to increase the capacity of body's weight support offered by the footwear and to modify the pronator or supinator moments around foot's joint axes.

- Bars are sole modifications with the purpose of redistributing pressure on metatarsal heads (metatarsal bars), supporting the midfoot (Thomas bar) or facilitating the forward movement around the metatarsophalangeal joints as pivoting centers (rockers bar).

- Sole stiffener in the form of steel shank or carbon fiber plate has the role to stiffen the sole in order to prevent motions in the different joints of the foot as in the case of the rocker soles [35].

- Sole material's stiffness/hardness should be indicated based on range of values (for example 50-60 Shore A) or based on a qualificative (for example: high stiffness, medium stiffness or low stiffness). It has to be indicated when the equilibrium between pronator and supinator moments around subtalar joint can be influenced in a negative way (for example when a foot orthotics is prescribed in order to increase the supinator moments but this effect is canceled or diminished by a low stiffness sole).

- Medial stabilizer for midfoot area (buttress) has the role of increasing the supinator moments around subtalar and midtarsal joint through a support placed outside of the shoe in the medial area of the longitudinal arch.

- Heel height will give the shoe's final heel height. As described above, in the case of lower limb discrepancy, when a tapered raise is prescribed, 
the measurement of the heel height and under metatarsophalangeal area should be provided [28].

- Shoe's toe rise represents the height of the distal point of the bottom of the shoe sole. Similar with rocker's angle, its purpose is to facilitate the forward movement around the third pivoting center which are the metatarso-phalangeal joints. It should be mentioned that the shoe toe rise is not to be confused with the last toe rise.

- Foot drop is mentioned as a sport footwear characteristic having the potential to influence biomechanics of sport activities [42, 43]. It is defined as the difference between heel and forefoot heights.

\section{Shoe Uppers' Prescription Variables}

- Shoe style (for example: Derby, Oxford, Mary Jane, sport, etc.) [44]. The upper's prescription variables are essential in the context of the importance of the shoe design and its influence on the patient adherence to the conservative treatment [45]. For this reason, prescription variables which are related to the footwear design should be included in the medical prescription. The decision regarding the shoe style should be taken in agreement with patient's expectation with a positive effect on the footwear acceptance as a treatment option.

- Shoe type: high-low quarters (high - for partial foot amputee) [46].

- Heel stabilizers / counter reinforcement - in order to increase the pronator or supinator moments around subtalar joint $[46,57]$.

- Closing/closure system (lacing or velcro) - in order to facilitate donning/doffing.

- Seamless lining - to protect the dorsal surface of the foot especially in the forefoot area of the diabetic foot.

- Toe filler is used to balance the lever arm propulsion in the case of the shorter foot length-equinus or in the case of partial footamputations.

- Flexibile materials for upper parts - to accommodate local foot deformities (e.g.: a balloon patch).
- Valgus / varus strap are used to increase the supinator or pronator moments through a medial or lateral directed force at the level of uppers [47].

- Padded tongue, rim/minimal toe puff in order to protect the dorsal surface of the forefoot [47].

Shoe uppers have an increasing potential to alter foot biomechanics $[48,49]$ even if it is difficult to define clear prescription variables.

\section{PRESCRIPTION FORM AS A COMMUNICATION TOOL BETWEEN FOOT CARE SPECIALISTS}

Next to the legal responsibilities related to the content of the medical prescription, it is also an important tool for communication between the foot care team members. Taking into account the experience from the podiatry where the advances in the field of the theoretical models on foot function have led to debates [50] which raise questions regarding the way in which the new concepts are transposed into the practical description of the prescription variables, a simple way of the indication of the design characteristics is proposed:

- the medical footwear manufacturer is proposing his own template with standard definitions of the prescription variables. For example, a standard lateral flare could mean: maximum width of $6 \mathrm{~mm}$ in the cuboid area, starting and ending points from the most proximal point to the most distal point of the last bottom center line. A visual representation (sketch or technical drawing) of the manufacturer's standard definition of the prescription variable is recommended;

- when the medical practitioner is prescribing a different geometrical characteristic of a prescription variable, a specific blank template provided by the manufacturer will be used. On this template, the practitioner will provide all the necessary elements for those characteristics. Both the practitioner and the manufacturer should establish a communication protocol which will ensure that the manufacturer has well 
understood what the practitioner wants. Such a protocol could include a validation of the virtual design of the custom-made medical footwear prior to entering the manufacturing stage.

It is obvious that the prescriber shall think about and indicate any prescription variables which are considered essential for the medical footwear to achieve its medical objectives even if this variable is not clearly indicated in a prescription form. With the advance of the 3D CAD-CAM technologies, the problem is not whether a specific design could be manufactured but to think about how the functional description of the medical device is translated into prescription variables/design characteristics having the same signification for both the prescriber and the manufacturer.

\section{CONCLUSIONS}

This paper has presented a list of basic prescription variables of the medical footwear described in the medical literature and clinical practice. A list of 33 basic prescription variables which define the complexity of the footwear as medical device were identified. In order to avoid confusions in terminology, the term "medical footwear" is proposed as an unifying term for the footwear used as medical device in the conservative treatment of the foot and lower limb pathomechanics. Some of the prescription variables described are difficult to be managed in practice in a prescription form. However, the prescriptioner should be aware of any prescription variable which can influence the effectiveness of the medical footwear. It is the medical practitioner's responsibility to use his knowledge about foot pathomechanics and foot functioning models in order to establish the specific prescription variables of the medical footwear through a medical prescription.

\section{REFERENCES}

1. Assistive products for persons with disability - Classification and terminology, EN ISO 9999:2016, https://www.iso.org.

2. World Health Organisation, WHO, Priority Assistive Products List, 2016, http://www. who.int.

3. Healthcare Common Procedure Coding System, HCPCS Code A5501, Diabetic custom molded shoe, https://hcpcs.codes/a-codes/ A5501/.

4. Medical-grade Footwear - Prescribing medical aids and equipment, Queensland Government, Australia, https://www.health. qld.gov.au/mass/prescribe/footwear.

5. Frecklington, M., Dalbeth, N., McNair, P., Gow, P., Williams, A., Carroll, M., Rome, K., Footwear interventions for foot pain, function, impairment and disability for people with foot and ankle arthritis: A literature review, Seminars in Arthritis and Rheumatism, Available online 3 November 2017 In Press, Accepted Manuscript, https:// doi.org/10.1016/j.semarthrit. 2017.10.017.

6. Hutchins, S., Bowker, P., Geary, N., Richards, J., The Biomechanics and Clinical Efficacy of Footwear Adapted with Rocker ProfilesEvidence in the Literature, The Foot, 2009, 19, 3, 165-70, https://doi.org/10.1016/j. foot.2009.01.001.

7. Hatton, A.L., Rome. K., Dixon, J., Martin, D.J., McKeon, P.O., Footwear Interventions A Review of Their Sensorimotor and Mechanical Effects on Balance Performance and Gait in Older Adults, J Am Podiatr Med Assoc, 2013, Nov-Dec, 103, 6, 516-33.

8. Fisher, D.S., Dyrby, C.O., Mündermann, A., Morag, E., Andriacchi, T.P., In Healthy Subjects without Knee Osteoarthritis, the Peak Knee Adduction Moment Influences the Acute Effect of Shoe Interventions Designed to Reduce Medial Compartment Knee Load, J Orthop Res, 2007, 25, 4, 540-6, https://doi. org/10.1002/jor.20157. 
9. Khoury, M., Wolf, A., Debbi, E.M., Herman, A., Haim, A., Foot center of pressure trajectory alteration by biomechanical manipulation of shoe design, Foot Ankle Int, 2013, 34, 4, 593-8, https://doi. org/10.1177/1071100713477613.

10. Directive 2007/47/EC of the European Parliament and of the Council of 5 September 2007, Official Journal of the European Union, 21.9.2007, http://eur-lex.europa.eu.

11. Henderson, W.H., Lamoreux, L.W., The Orthotic Prescription Derived from a Concept of Basic Orthotic Functions, Bull Prosthet Res, 1969, Spring, 89-96.

12. Janisse, D., Working with physicians: Footwear Prescriptions, OPEDGE, September 2013.

13. Fisk, J.R., DeMuth, S., Campbell, J., DiBello, T., Esquenazi, A., Lin, R.S., Malas, B., McGuigan, F.X., Fise, T.F., Suggested Guidelines for the Prescription of Orthotic Services, Device Delivery, Education, and Follow-up Care: A Multidisciplinary White Paper, Mil Med, 2016, Feb, 181 (2 Suppl), 11-7, https://doi. org/10.7205/MILMED-D-15-00542.

14. Prescribers, Enable NSW Health Support Services, New South Wales Government, Australia, http://www.enable.health.nsw. gov.au/home/prescribers.

15. Medical prescription-recommendation on granting medical devices for the rehabilitation of some organic or functional impairments, Annex 39D from the Order no. 763/2016, http://www.cnas.ro.

16. Denischi, A., Medrea, O., Popovici, N., Diseases of the foot (in Romanian), 1964, Ed. Medicala, Bucharest.

17. Petcu, D., Rosculet, V., Regulation for the prescription of footwear as medical device, Leather and Footwear Journal, 2017, 17, 1, 59-66, https://doi.org/10.24264/Ifj.17.1.8.

18. Banwell, H.A., Mackintosh, S., Thewlis, D., Landorf, K.B., Consensus-based Recommendations of Australian Podiatrists for the Prescription of Foot Orthoses for Symptomatic Flexible Pes Planus in Adults, J Foot Ankle Res, 2014, 7, 49, https://doi. org/10.1186/s13047-014-0049-2.

19. Landorf, K., Keenan, A.M., Rushworth, R.L., Foot Orthosis Prescription Habits of Australian and New Zealand Podiatric Physicians, Am Podiatr Med Assoc, 2001, 91, 4, 174-183.

20. Menz, H.B., Allan, J.J., Bonanno, D.R., Landorf, K.B., Murley, G.S., Custom-made foot orthoses: an analysis of prescription characteristics from an Australian commercial orthotic laboratory, J Foot Ankle Res, 2017, 10, 23, https://doi. org/10.1186/s13047-017-0204-7.

21. Kennedy, S., Custom Shoes: The Importance of the Cast, The O\&P EDGE, November 2009.

22. Kramer, C., Treatment of talipes equini: correction options in functional and structural talipes equini, Foot \& Shoe, 2015, 1, 26-31.

23. Maurer, G., Case Report - Custom-made footwear after prior trauma, Foot \& Shoe, 2014, 2, 20-26.

24. Edwards, C.A., Orthopedic Shoe Technology for the Orthopedic Shoe Technician, Precision Printing Co, 1st edition, 1981.

25. Edwards, C.A., Orthopedic Shoe Technology Clinical Conditions Requiring Orthopedic Footgear, Precision Printing Co, 1st edition, 1985.

26. Kapp, S., Cummings, D., Transtibial Amputation: Prosthetic Management, in Atlas of Limb Prosthetics: Surgical, Prosthetic, and Rehabilitation Principles, Rosemont, IL, American Academy of Orthopedic Surgeons, edition 2, 1992, reprinted 2002.

27. Dananberg, H., Comfortable High Heel Shoe, US Patent US5782015, July, 21, 1998.

28. Tyrrell, W., Carter, G., Treating patients with complex pathologies in Therapeutic Footwear: A Comprehensive Guide, Elsevier Health Sciences, 2009, 196-223.

29. Roniger, L., When the shoe doesn't fit: footwear in Down syndrome, Lower Extremity Review, May, 2016. 
30. Chen, R., An investigation into shoe last design in relation to foot measurement and shoe fitting for orthopaedic footwear, PhD Thesis, University of London, June 1993.

31. Rossi, W.A., Why Shoes Make "Normal" Gait Impossible, Podiatry Management, March 1999.

32. Maas, J.C., Dallmeijer, A.J., Huijing, P.A., Brunstrom-Hernandez, J.E., van Kampen, P.J., Jaspers, R.T., Becher, J.G., Splint: the efficacy of orthotic management in rest to prevent equinus in children with cerebral palsy, a randomised controlled trial, BMC Pediatr, 2012, 12, 38, https://doi.org/10.1186/14712431-12-38.

33. Chen, W., Pu, F., Yang, Y., Yao, J., Wang, L., Liu, H., Fan, Y., Correcting Congenital Talipes Equinovarus in Children Using Three Different Corrective Methods A Consort Study, Medicine (Baltimore), 2015, Jul, 94, 28, e1004, https:// doi.org/10.1097/MD.0000000000001004.

34. Allen, W.D., Weiner, D.S., Riley, P.M., The Treatment of Rigid Metatarsus Adductovarus with the Use of a New Hinged Adjustable Shoe Orthosis, Foot Ankle, 1993, Oct, 14, 8, 450-4.

35. Kennedy, S., If the Shoe Fits... Pedorthic Modifications for Optimal Function - The O\&P EDGE, April, 2006.

36. Bennell, K.L., Kean, C.O., Wrigley, T.V., Hinman, R.S., Effects of a Modified Shoe on Knee Load in People with and Those without Knee Osteoarthritis, Arthritis \& Rheumatism, 2013, 65, 3, 701-9, https://doi.org/10.1002/ art.37788.

37. Kean, C.O., Bennell, K.L., Wrigley, T.V., Hinman, R.S., Modified Walking Shoes for Knee Osteoarthritis: Mechanisms for Reductions in the Knee Adduction Moment, $J$ Biomech, 2013, 46, 12, 2060-66, https://doi. org/10.1016/j.jbiomech.2013.05.011.

38. Preece, S.J., Chapman, J.D., Braunstein, B., Brüggemann, G.P., Nester, C.J., Optimisation of rocker sole footwear for prevention of first plantar ulcer: comparison of group-optimised and individually-selected footwear designs, J Foot Ankle Res, 2017, 10, 27, https://doi. org/10.1186/s13047-017-0208-3.

39. Nigg, B., Federolf, P.A., von Tscharner, V., Nigg, S., Unstable shoes: functional concepts and scientific evidence, Footwear Sci, 2012, 4, 2, 73-82.

40. Petcu, D., Bucur, D., Karavana, H.A., Nistor, M., Pantazi, M., Georgescu, M., The influence of the rocker sole profile's orientation on the sagittal ankle range of motion, The 4th IEEE International Conference on $\mathrm{E}$-Health and Bioengineering - EHB 2013, lasi, Romania, November 21-23, 2013.

41. Wu, W.L., Rosenbaum, D., Su, F.C., The Effects of Rocker Sole and SACH Heel on Kinematics in Gait, Med Eng Phys, 2004, 26, 8, 639-46, https://doi.org/10.1016/j. medengphy.2004.05.003.

42. Herbaut, A., Simoneau, E., Barbier, F., Roux, M., Guéguen, N., Chavet, P., Lower shoe drop can reduce impact forces experienced by junior tennis players performing an openstance forehand, Footwear Sci, 2015, 7, sup1, S112-S113, https://doi.org/10.1080/194242 80.2015 .1038638 .

43. Besson,T.,Morio,C., Rossi,J.,Effectsofshoedropon running mechanics in women, Comput Methods Biomech Biomed Engin, 2017, 20, sup. 1, 19-20, https://doi.org/10.1080/10255842.2017.13828 40.

44. Tyrrell, W., Carter, G., It's not 'just a pair of shoes' in Therapeutic Footwear A Comprehensive Guide, Elsevier Health Sciences, 2009, 1-18.

45. Boulton, A.J., Jude, E.B., Therapeutic footwear in diabetes: the good, the bad, and the ugly? Diabetes Care, 2004, Jul, 27, 7, 1832-3.

46. Kirby, K.A., Shoes and therapy in the treatment of posterior tibial dysfunction, Precision Intricast Newsletter, Precision Intricast Inc., Payson, Arizona, May, 2000, 105-106.

47. Zamosky, I., Shoe modifications in lowerextremity orthotics, Bull Prosthet Res, 1964, 10, 2, 54-95. 
48. Nigg, B., Biomechanics of Sport Shoes, Edited by Benno Nigg, Printed in Canada by Topline Printing Inc. Calgary, Alberta, 2010, ISBN: 978-0-9867421-0-1.

49.Villwock, M.R., Meyer,E.G.,Powell,J.W., Fouty, A.J., Haut, R.C., Football Playing Surface and Shoe Design Affect Rotational Traction, Am J Sports Med, 2009, Mar, 37, 3, 518-25, https:// doi.org/10.1177/0363546508328108,Epub 2009 Jan 23.

50. Groner, C., Study challenging Root concepts reignites debate, Lower Extremity Review, June 2017.
(C) 2017 by the author(s). Published by INCDTP-ICPI, Bucharest, RO. This is an open access article distributed under the terms and conditions of the Creative Commons Attribution license (http://creativecommons.org/licenses/ by/4.0/). 